\title{
SOME ASPECTS OF THE IMPACT OF THE INTERNET ON ACCESS TO INFORMATION
}

\author{
Michael W. Hill \\ Formerly Director, Science Reference Library, the British Library
}

We live in interesting times. There is no peace. Before we have adjusted to one new technology another is upon us and we have to start the adjustment process all over again. A period of calm in which to resolve how our needs can best be met is denied us. We are robbed of sufficient time to experiment thoroughly and systematically by improvements to each new technology of such frequency and magnitude that the equipment or system is obsolete before the research is finished.

A slight exaggeration perhaps, but not much, particularly when the modern information and communication technologies (ICTs) are being considered. Nevertheless, it is necessary to try to stand back for a moment from the forefront of progress and try to judge where the latest ICTs are leading us, what the consequences are likely to be and what changes we must make to how we work in order to gain maximum benefit and minimum disbenefit.

If we look back at the history of ICTs, we find that previously, after the excitement of each new technology, there has come about a rebalancing of all the then existing ones. Even today recording on stone is still used but only for static monuments. Printing did not eliminate manuscript, nor did the telephone, though first typing and now e-mail are greatly reducing the number of manuscript letters. We must, therefore, anticipate some redistribution of tasks for which each of the following is used:-

$\begin{array}{ll}\text { engraving } & \text { voice } \\ \text { manuscript writing/typewriting } & \text { smoke signals } \\ \text { printing } & \text { flag signals } \\ \text { microfiche/microfilm } & \text { telegraph/telegram/telex } \\ \text { television } & \text { radio } \\ \text { tape recording } & \text { fixed telephone/fax } \\ \text { CDs } & \text { mobile phones/text messaging } \\ \text { Internet/web sites } & \text { e-mail and Intranet }\end{array}$

Of course, a technology can serve more than one purpose. This is particularly true of the Internet, which is only a system for interconnecting a vast number of computers together on a world-wide scale. Thus it facilitates correspondence to be sent simultaneously to many recipients, it enables computer to computer discussion groups to be set up, and it enables remote stores of information, text and pictures to be interrogated. For this it is necessary, of course, that all the communicating equipment and systems are compatible. Therein may lie one of the major problems of the future. Text stored using today's equipment/systems may prove inaccessible to the equipment/systems of the future.

It is an oft repeated platitude that the Internet enables all the peoples of the world to 
communicate with each other and to access all the information in the world. And, like all platitudes, it is only partially true. For those who can afford a computer and can learn the skills, it brings huge benefits but one does not use it to the exclusion of other ICTs. For example a telephone allows the subtle shades of meaning conveyed by the nuances of the human voice to come into play. E-mail is a very impersonal method of communicating compared with a letter, especially a manuscript one.

Nevertheless, the e-mail facility that the Internet allows is, on the whole, beneficial as far as the dissemination and growth of information and knowledge is concerned. It is much faster than postal services and unlike the telephone it does not require the recipient to be present at the time of sending. Answerphones, though useful, are not an adequate alternative. It has the huge advantage that the same message, or request for information, can be sent simultaneously to a large number of people in the expectation that, at least one will respond with the answer wanted. Experts may, however, find this a nuisance if they get too many requests, especially from schoolchildren undertaking "projects".

Unfortunately, e-mail has also raised a new barrier. Many newsletters that were previously printed and distributed free are now distributed only as attachments to e-mails. As a result those who do not have access to e-mail facilities are deprived of an information source that once they had. In industrial countries libraries provide access for the poor to e-mail and the Internet generally. In general, this is not so in the poorer developing countries. Fortunately, even in the poorest countries, there are some organizations which have acquired or been donated means to access the Internet, though without back-up electrical generators there may be problems from time to time of power supply. Among such organizations are hospitals and universities. For these arrangements are being made by UN and some professional bodies in industrial countries to provide free on-line access to publications. One huge advantage of the Internet is that the cost of providing access to one more customer is trivial.

\section{Quality Problems}

When we turn to the question of the value and reliability of information sources accessed through the Internet, interesting questions arise, especially if we try to compare these aspects with access to equivalent sources by more traditional means. For this it can be helpful to divide the use of the Internet into its three basic modes:

(a) person to person, whether one to one or one to many;

(b) person to known website;

and

(c) person to Search Engine.

In the first case the situation is no different from when one is seeking information by letter or telephone. This applies whether the information sought or gained via e-mail, Discussion Groups or Bulletin Boards. In each case one is getting information from individuals and one simply uses one's own judgement of the knowledge and reliability of those individuals.

In the second case one has to rely on the website but here too one's experience comes into play. If the website is that of a distinguished professional body one would accept what one finds just as one would information it had put out in print. So one would do also with a newspaper's 
website. One judges what one finds on a website by the reputation of its owner

High calibre scientific journals submit new research papers to the peer review process, but even this is not infallible. Errors are revealed by subsequent research and the correct results then published. Searching for a subsequent paper in printed journals is greatly assisted by Citation Indexes. One hopes these will continue at least until searching electronic publications by key words in context or by citations is proven to be at least as efficient.

It is when one uses a Search Engine that problems may arise. These Engines do not validate information. They do not institute any process of peer review. They simply search for terms in all the stored text in computers to which they have access and many people and organizations have made a vast mass of information, ideas and beliefs available to those who search the Net. One could argue that a vast mass has similarly been made available in books and journal articles but in these cases there has usually been a measure of control. Publishers have always been wary and even if peer review has not been instituted their editors have been watchful. Self publishing is expensive and thus the amount of nonsense published in conventional format is limited. The Internet, on the other hand, allows publishing at very small cost and as a result not only sound material is published but also, sadly, a great deal of material of dubious validity. A search for information rarely reveals who is the source of the information accessed. Those who search need to be wary and when there is need try to establish some way of checking the reliability of the answer. But one must not exaggerate the problem. For many searches the result is quite acceptable, simply using one's common sense to test the likelihood of the result being right.

Thus when today I searched via the Search Engine "Google" to find the date when the UK Freedom of Information Act was passed, and found the answer December 2000, my knowledge of the topic led me to believe this to be probably correct or I could then cross-check with a list of Parliamentary Proceedings for that date. The main problem was the vast amount of related but irrelevant information that the search revealed. Fortunately what I wanted appeared with very little scrolling.

One website which provided an extreme example of unreliable information was the Friends United Site. It aims to enable former school and college friends who have many years ago lost contact to renew contact. Anyone wishing to contact former friends simply posts his personal details with a short message. Unfortunately, one person used the facility to post a libellous message about a schoolmaster who had taught this person and his friends. The message has now been deleted, but how many more deliberately erroneous messages have been placed on websites? As everyone knows, there are many people who will not accept the conclusions of scientific research and insist that contrary statements must be taught in schools. Do they not also disseminate their beliefs via the Internet? Indeed, it is well known that there is some information accessible via the Net which is accidentally erroneous, some which is the result of erroneous belief, and some which is deliberately erroneous but, making searches generally worthwhile, much, much more which is correct.

Making new research accessible

Already the Internet is changing the way research is published and is changing the way the researcher finds records of research conducted previously. It is, therefore, important that re- 
search workers generally clarify exactly what sort of information they need, in what form and how they can get it most efficiently so that they can provide clear input to publishers, professional societies, information professionals and others who will be involved in the Internet-based publishing chain.

As is only too well known, the traditional system of printed journals has become less and less efficient and more and more cumbersome and expensive as the amount of research has grown. It has also become messy. In the second half of the 20th century, the normal pattern of publishing has been first a Note to Nature followed in due course by the full paper in a journal. Later still an abstract appeared in one or more abstracting journals and in on-line services. If one did not have the relevant issue of the journal nearby, one had to get a photocopy. But, not all new papers appeared in journals. Many were published as conference proceedings, copies of which could be very difficult to track down. Some appeared in Report Series. For social scientists official publications and semi-official ones were important and so too were a wide range of ephemera. Tracking information was getting more and more difficult.

Apart from the delays between submitting a paper and its appearance in print, and the increasing costs of journals, there was the added irritation that the journals carried a wide range of articles, many of which were irrelevant to the researcher's interests. Speed of availability, ready access and ability to identify immediately relevant papers at a low cost became increasingly important.

Berners-Lee conceived the World-Wide-Web as a means of achieving immediate publication, overcoming the lengthy delays that had become normal in the print-on-paper journals but, I believe, he did expect the electronically published articles to be subsequently published in the conventional, peer- reviewed journals. Publishing on the WWW enabled those currently researching in a field in widely scattered laboratories to keep right up-to-date. Any strange results could be immediately queried.

Immediate access to current research by colleagues elsewhere is not the only information need researchers have. When starting a project one first wants to find out what is already known and what work has been done so far. During the research one will need all sorts of data, for example chemical, physical and biological properties of materials. One needs to read around one's subject in order to get ideas, which often arise from other disciplines. One may need news of new apparatus, new inventions and new materials which might be useful. In some disciplines, research published many years ago is still valuable so some form of archival store is vital.

It is important, when considering how information is to be accessed, to keep in mind that a great deal is acquired during informal discussions with fellow research workers, not just those in one's own field of work but also those on other research and in other disciplines. Commonly this occurs over coffee, at lunch or dinner or over a drink in the bar even more than in the laboratory. While there is no doubt that e-mail and Internet discussion groups are supplementing this by encouraging informal contact with researchers in other laboratories and may partially replace some formal conferences too, I doubt if face to face contacts in a sociable setting will ever be entirely replaced by the screen. Such modes of gaining information and exchanging ideas are not merely a result of the frustrations that paper-based sources of information can arouse.

The Internet has already led to research papers (and much else such as newspapers) being 
published both in paper copy and in electronic version. Already some publications appear in electronic version only. If the paper is submitted electronically the only delays should be any editing and peer review and even those should much quicker than before. Costs exist and have to be met. Will advertising on the site provide much revenue? One doubts it. Two alternatives exist. First the obvious one that users have to pay an access fee and second that the author pays a fee. This is the system that the publisher Biomed Central is adopting.

A crucial aspect of using articles on a publisher's website is that searching using keywords shall reveal only wanted papers. It must be very doubtful if the labour intensive abstracting services will continue very much longer, even as on-line services, when direct searching becomes the norm. One does not want to have to sift through all the unwanted articles as one did with the printed journal. Also there should be no undue difficulty in the way of reading the paper and getting a print out. Paying a fee for a copy must be simple for a once-only user.

Searching using keywords in one's own discipline should rarely create a problem. Difficulty may arise when searching in a different discipline in which one is not familiar with all the technical terms. There will be a need for good glossaries. These should be available on the Net so that one can find the term which expresses a concept, a task difficult with printed glossaries in which entries are all under the term.

\section{Archiving}

In general I am optimistic that as problems arise from increasing dependence on the Internet and access to sites researchers will find answers. One project to tackle some of the questions is already underway known as the Budapest Open Access Initiative (BOAI). One approach it is examining is the creation of new, non-copyright journals. Another is self-archiving.

However, there is one major anxiety in my mind which has arisen already in the case of on-line abstracting services. It is that only a limited retrospective data-base has been stored. When one attempted to search back in on-line data-bases one often found that only about 20 years retrospective entries were stored. For earlier entries one had to use the printed abstracting journals. That was not very serious because the printed issues existed, stored in big national and academic libraries. However, if research papers in future exist only in electronic form, how shall we find back copies if only those of recent date are kept on the website?

Whatever system of publishing new research emerges, it is vital that back research should be accessible. It may be that the national libraries or some other organizations of guaranteed permanence should be required to accept the role of storing archivally records of research. Other than printing paper copies and distributing them to several such centres, it is difficult to see at this stage what reliable system can be set up. One hopes that the BOAI will see a way forward. Until one is found, the learned and professional societies must be urged to maintain their printed journals as a service to their members, archival copies being deposited in national and academic libraries. 
情報知識学会誌 Vol.12, No.2

抄訳

\section{インターネットの情報アクセスへのインパクトの諸問題}

マイケル W. ヒル (元大英図書館、科学資料図書館長)

新技術の開発が相次ぎ、それへの対応に追われる現代は、面白い時代であるが当事者にとって は心の休まる時がない時代である。その当事者が直面している問題をあげてみよう。

問題は ICT(Information Communication Technology 情報通信技術)にとくに顕著である。本 稿は、このICT についての変化の状況を先ず見ることにする。

まず ICT の変化の歴史 (本文参照)。

現代 ICT の一つの特性は、それが一目的対応に限定されないことである。このことはとくに全 世界の膨大なコンピューターが接続するシステム、すなわちインターネットで顕著である。これ は実は、すべての通信機器、ないしシステムが互換性をもつことを要請しているのであり、これ が将来の根本問題となる可能性を孕んでいる。すなわち、今日のシステムないし装置に入力され たコンテンツが、明日は取り出せなくなる可能性があるのである。

インターネットは個人と全世界との会話を可能にした。その便利さは巨大だが、全能ではない。 例えば、電話は音声の微妙な意味付けを可能にする。同様に、文字の文章や手書きの手紙も E-mail では不可能な人間の息づかいを伝える。もちろん、インターネットが量的に拡大化するばかりの 情報の流通に果たす利便はいうまでもない。とくに一つの通信を多数人に同時に発信するとか、 逆に受け得るのは大変な便利である。しかし、それにも限度があり、質問が殺到し、それへの応 答が要求されるような場合には用をなさない。

インターネットのもう一つの不便は電子機器の装置の普及の問題である。開発途上国などにお ける不便さは大きな問題として残っている。とくに電気のない地域の問題は深刻で、病院や大学 などでこれは大きな問題である。国連その他の援助があることは記録さるべきである。とくに、 それで出版物のオンラインアクセスが可能になる意義は大であり、それに比べればアクセスコス トが小さいことである。

情報の質の問題 :

インターネットによる情報取得における情報源の価值と信頼性は大問題である。これを (a) 個 人対個人、(b) 既成 Web サイト利用、(c) サーチエンジン利用の 3 つのモードに分けて考えて見 よう。(a) は E-mail を使うとしても、評価は検索者自身でしなければいけないから旧来と変わら ない。(b) は Websiteの能力に結果を依存する。だから、Website の能力、その評価にたよること になる。問題は (c) である。ここでは評価なしの情報が大量に出力される。もちろん旧来の書物 や学術雑誌から得られる内容も同様に大量であるけれども、後者の場合は質についての査読を経 ている点が根本的に違う。サーチエンジンの場合は情報源すら明らかでない場合すらある。ただ し、この点を誇張すべきではない。要は注意深く検索者が評価すればよい。それには、別の項目 名によってクロスチェックするのがよいであろう。

新研究情報の検索：

インターネットが研究者の発表手段や既往の研究情報の取得法を変えたことは確かである。 World-Wide-Web は研究結果の即時周知 (immediate publication) を可能にした。このことの本 当の価值は、普通言われるような、遅い旧来の学術雑誌の刊行の遅れを無くしたことではない。 そうではなく、電子出版の結果、研究室の研究者が現在やっている研究対象について、即時的に、 
世界に広く分布する関連研究者の研究現況を、指標ジャーナルで把握出来るようにしたことであ る。例えば、そこで不審な妙なことがあると気づいた研究者は、直ちに当人に照会する利便を得 るのである。

ところで、研究者にとって必要なのは、他人の研究の様子を即時的に知ることだけではない。 新たにプロジェクトを始めるときは、これまでに何が分かり、どんな研究がなされたかについて の知識が必要なのである。その時役に立つのは、自分の専門外の分野での新装置や新手段、関連 する物理、化学、生物学の知見、そこのアイデアを知ることであり、しばしば、そこの古い記録 が有用なことが起こるのである。それ故、保存記録の価值は無くならない。

研究者にとって役にたつ情報の大部分は、同僚、それも同じ実験室の人だけでなく、違う分野の 人との特に非公式な場での会話で得られるのである。それも、同僚とのコーヒーや、ランチやデ イナーや、ラウンジの雑談でも起こるのであり、実験室内だけの生活からは生まれないし、E-mail 情報からも生まれないものである。face to face contact の意義が失われることはないであろう。 学術誌の出版の遅れで情報の獲得とアイデアの交換が出来ないとよく言われ、電子出版がその欠 を埋めると言われたが、それは違う。

電子出版は時代の趨势である。その場合のコストを誰が負担するかは今後の問題であろう。広告 に依存する策は疑問。可能な対応は二つである。利用者負担か著者負担。後者は出版社の Biomed Central がすでに採用した。利用者負担は現実無理がある。事項検索で得られる情報は膨大で、 一々それに費用を支払うことを単純な検索者に求めるのは無理がある。

専門分野のキーワード検索から新問題 (研究対象) を生むことは考えられない。さらにまた、自 分の専門分野でない分野で慣れないキーワードで検索しても好結果をすぐ生むとは思えない。こ の場合は、グロッサリー (総合検索語集) 支援が欲しい。それには、事項の概念を指示してくれる グロッサリーをネットが供給してくれることが望まれる。このグロッサリーは固定ターム (事項) で構築された印刷体では作れない。ネットの機能に期待せざるを得ない。

\section{資料保存}

筆者は、研究者がインターネット依存に走るために起こるとされる問題には楽観的である。 研究者自身が解決するだろうと思う。ブタペスト オープン アクセス (Budapest Open Access Initiative, BOAI) は，指摘されている問題を解決する試みとしてすでに始まった、新しい、コピー ライト無縁ジャーナル収集の例である。これに代わるもう一つは、自分でやる方式 (self-archiving) である。

筆者はオンラインアブストラクトについて大きい危惧を持つものである。現在のデーターベー スはわずか 20 年分しか遡及出来ない。それ以前の分は、資料が必要となれば、国立中央図書館や 大学図書館にゆけば事が足りる。しかしながら、今後、資料保存が website だけになったときは、 遡及検索はどうなるか。心配せざるを得ない。

新研究の出版がどのようになろうとも、過去の研究の知見を知り得るようにしておくことは絶 対必要事である。研究記録の永久保存を使命とする国、ないし、それを保証する図書館の建設が 必要である。印刷体以外のコピーをこの主の図書館に配布するシステムが出来ようとは思えない。 BOAI がその責めにつくことは望まれるが、それが出来るまでは、当面、諸学会が印刷体を維持 し、これをしかるべき保存図書館に寄付し、保存をはかることを熱望してやまない。 